\title{
Isolation and Purification of Novel Anti-Fungal Peptides from Hemolymph of Immunized Larvae of Housefly, Musca domestica
}

\author{
Li-Juan $\mathrm{Gu}^{1,2}$, Jian-Wei $\mathrm{Wu}^{1 *}$, Xiao-Qing $\mathrm{Su}^{1}$ and Chang-Keun Sung ${ }^{2}$ \\ ${ }^{1}$ Gui Yang Medical College, Gui Yang 550004, China. \\ ${ }^{2}$ Department of Food Science and Technology, College of Agriculture and Biotechnology, \\ Chungnam National University, Taejon 305-764, Korea.
}

Received January 26, 2006 / Accepted March 17, 2006

\begin{abstract}
To isolate and purify anti-fungal active substances from immunized housefly (Musca domestica), low dose of Candida albicans was injected into the larvae of the housefly to induce the appearance of potent anti-fungal active substances in the hemolymph. This purification work was performed by the routine isolation and purification processes of protein, namely, solid phase extraction (SPE), SDS-PAGE electrophoresis, HPLC purification. Three $4 \sim 16 \mathrm{kDa}$ peptides which exhibited antifungal activity against Candida albican and other fungi were isolated from induced hemolymph. Consequently, further anti-fungal activity study showed that these three peptides were different either in molecular weight or in anti-fungal activity. All isolated substances were proved to be active and resistant to high-temperature. It was deduced that these peptides isolated from induced housefly were novel members of the insect defensin family and they were inducible.
\end{abstract}

Key words - Anti-fungal peptide, Candida albican, hemolymph, housefly larvae, HPLC, SPE.

\section{Introduction}

Living organisms are exposed daily to microbial infections and other pathogens, and in order to defend themselves against the abrasive environment, they have developed potent defensive mechanisms that are parts of innate and adaptive immunity. The innate immune system is the first line of inducible host defense against bacterial, fungal, and viral pathogens[9]. This defense system is essential for the survival and perpetuation of all multicellular organisms[11,22]. In vertebrates, defense reactions rely on both innate and adaptive immunity, while in invertebrates, only innate immunity is presented[11]. Insects lack an acquired immune system but have a well-developed innate response. The epithelial surfaces of the body serve as first-line defenses against microorganisms. At epidermis, the cells of the digestive and genital tracts, if the tracheas and of the Malpighian tubules produce antimicrobial peptides, which can inhibit microbial growth[12]. At present insects are found in most of the biological niches except for the deep marine environment and polar regions $[4,25]$. Consequently, they are confronted by an extremely large variety of potentially harmful microorganisms. The resist-

${ }^{*}$ Corresponding author

Tel : +86-851-690-9979, 86-13007836719, Fax : +86-851-690-9979

E-mail : wjw@gmc.edu.cn ance of insects to pathogens has certainly contributed to their extreme proliferation and diversity. Researchers had already fully appreciated that insects are able to build up an efficient defense against microorganism and it was understood that this defense involved effective immune systems, both a cellular and a humoral facet[3]. Many insects respond to an injection of live, non-pathogenic bacteria with the production of a potent cell-free antimicrobial activity[1]. The production of antimicrobial substances is benefical to insects to resist on invasion of pathogens[10]. Among these antimicrobial substances, antimicrobial peptides were extensively studied. The intensive application of antibiotic agents in health care and animal breeding during the last decades has created a continuous selective pressure on microorganisms. The growth and spread of microorganisms are implicated in resistance against one or several of the present antimicrobial agents. Thus, the development of novel antimicrobial agents requires novel active lead -compounds. The innate immune system of insects has proven to be a source of a large variety of such compounds and in particular of antimicrobial peptides [4,20]. Antimicrobial peptides, a kind of important components of the natural defenses of most living organisms against invading pathogens, have attracted more and more attention because of their potential applications in medicine and industry. So far more than 750 different antimicrobial pep- 
tides have been identified in various organisms ranging from insects to plants or to animals including humans[21]. More than 50 antibacterial moleculars, which are all cationic peptides or polypeptides, have been isolated from the blood of immune-challenged insects[14]. There are seven inducible antimicrobial peptides in Drosophila, which are transcribed in the fat body within hours of an immune challenge and are secreted into the blood; Drosomycin, Metchnikowin and Cecropin are activly against fungi; Defensin and Metchnikowin against Gram-positive bacteria and Attacin, Cecropin, Diptericin and Drosocin against Gram-negative bacteria[4,18]. However, very few inducible anti-fungal peptides had been described so far from common housefly. The housefly is an important cosmopolitan and the most familiar nuisance pest which spends its life in more frequently in silt and can cause human and animal myiasis. However, housefly never suffered from any diseases. This fact indicates that housefly possesses strong immune system. In this persent research, we have found that fungi growth was inhibited by treating with the hemolymph collected from fungi-immunized housefly larvae. Further, hemolymph of immunized larvae of housefly exhibited anti-fungal activity. These results provided clues and basic work to develop new drugs from housefly to treat fungal infection of human body. On the other hand, housefly is frequently used in biochemical, genetic, medical and veterinary importance worldwide. Moreover, its biology and ecology makes it an ideal mechanical vector of human and animal pathogens including viruses, bacteria, protozoan cysts and helminth eggs. The present study was reported the peptides from the hemolymph of immune induced housefly larvae and showed the their exclusive anti-fungal activity. This study focused on the isolation, purification of three peptides from hemolymph of larvae of housefly and detection of anti-fungal activities against Candida albicans.

\section{Materials and Methods}

\section{Fungi strains used in assays}

Candida albicans (Candida albicans(Robin) Berkhout 1923)

were obtained from ShangHai Second Medical University (ShangHai, China). Total 3 strains were used: strain 08, strain 09 and strain 19. Strain 19 is the most antibiotic sensitive strain for Fluconazole-resistant, while strain 08 is moderate-resistant and strain 09 is non-resistant.
Insects, their inducement, collection of hemolymph and sample preparation

Housefly (Musca domestica) were trained by Department of Parasitology, Guiyang Medical College (Guiyang, China) and reared with milk powder and wheat bran diet. The three-day-old larvae were vaccinated by injecting approximately $10^{6}$ viable log-phase (with an optical density of $500 \mathrm{~nm}$ of 0.4 ) cells of C. albicans strain 08[2,13]. After 48 hours the larvae were disinfected with alcohol and hemolymph was collected in tubes containing a few crystals of phenylthiourea by cutting their heads. The hemocytes were removed by centrifugation at $2,000 \times \mathrm{g}$ for $15 \mathrm{~min}$. The supernatant was used immediately or stored at $-70^{\circ} \mathrm{C}$. From this stage to all the purification steps were performed at $0-4{ }^{\circ} \mathrm{C}$. In parallel, an identical volume of hemolymph from unchallenged larvae was treated under the same conditions.

\section{Pre-purification of hemolymph}

Step 1. Supernatant was heated at $100^{\circ} \mathrm{C}$ for $30 \mathrm{~min}$, subsequently the Hemolymph was centrifuged at $12,000 \times \mathrm{g}, 4^{\circ} \mathrm{C}$ for $15 \mathrm{~min}$. The supernatant was used in the second step.

Step 2. Precipitation with solid ammonium sulfute[19]: Ammonium sulfate concentration of the precipitation was brought to $30 \%$ saturation with solid ammonium sulfate and allowed to stand at $4^{\circ} \mathrm{C}$ overnight. The turbid solution was centrifuged at $12,000 \times \mathrm{g}, 4^{\circ} \mathrm{C}$ for $15 \mathrm{~min}$ and the supernatant was brought to $80 \%$ saturation concentration by addition of solid ammonium sulfate and allowed to stand at $4^{\circ} \mathrm{C}$ overnight. The resulting precipitate was collected by centrifugation at $12,000 \times \mathrm{g}, 4^{\circ} \mathrm{C}$ for $15 \mathrm{~min}$. Ammonium sulfate pellets were resuspended in distilled water and dialyzed extensively to get rid of $\mathrm{SO}_{4}{ }^{2-}$ and $\mathrm{NH}_{4}{ }^{+}$. The dialyzed solution was ready for further purification.

\section{Procedures of purification}

Step 1. Purification as solid phase extraction on Sep-Pak cartridges (Waters, U.S.A.)[16]: Sep-Pak cartridge was conditioned with $0.1 \%$ trifluoroacetic acid [15] and flow rate was maintained at $5 \mathrm{ml} / \mathrm{min}$. The dialyzed solution was loaded on to Sep-Pak cartridges, elutions were performed with stepwise concentrations of $5 \mathrm{ml}$ acetonitrile (ACN) (from 10 to $100 \%$ ) in acidified water $(0.05 \%$ TFA), and elution was controlled with flow rate of $1 \mathrm{ml} / \mathrm{min}$. Fractions eluted from every concentration were collected and dried under a vacuum by evaporating acetonitrile totally. Dried 
substances were dissolved in distilled water for anti-fungal activity assaying.

Step 2. Purification by HPLC: Sep-Pak fractions with activity were subjected to RP-HPLC on a Sephasyl $\mathrm{C}_{18}$ col-

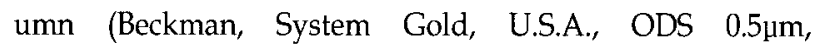
$0.46 \times 25 \mathrm{~cm}$ ). Elution was performed with a linear gradient of $25-100 \% \mathrm{ACN}$ in acidified water over $60 \mathrm{~min}$ at flow rates of $1 \mathrm{ml} / \mathrm{min}$. The fractions corresponding to absorbance peaks were collected in polypropylene tubes, dried, reconstituted in water, and tested for anti-fungal activity.

\section{Assay of anti-fungal activity}

Anti-fungal activity assay was performed according to previous method[23] with minor modification. Briefly, 200 $\mu$ ll of $10^{6}$ viable log-phase $C$. albicans, strain 08 , strain 09 and strain 19 were vaccinated on thin agarose plates, filter paper (round in shape, diameter is $5 \mathrm{~mm}$ ) fwhich contains $500 \mu l$ fractions was put on thin agarose plates. The samples without vaccination and with the antibioticsFluconazole were also put on the plates as the control and positive control, respectively. Plates were incubated overnight at $37^{\circ} \mathrm{C}$ and the diameters of zones were recorded. Anti-fungal activity was analysed by measuring the fungi growth inhibition zone.

After the pre-purification steps, one of the three purified active fractions from solid phase extraction, fraction $60 \%$ ACN, was performed to HPLC for further purification of the peptides. The peak that appeared after $12.5 \mathrm{~min}$ was obtained and test having antifungi activity. After anti-fungal assay of agarose plates, the anti-fungal activity of the purified peptide was measured by a liquid growth inhibition assay[7,8]. Briefly, viable log-phase C. Albicans strain 08 , strain 09 and strain 19 were centrifuged and suspended in ice-cold $0.1 \mathrm{M}$ phosphate buffer $\mathrm{pH} 7.0$ containing $60 \mathrm{mM} \mathrm{NaCl}$, to give a density of 30 units on a KlettSummerson colorimeter $\left(\mathrm{A}_{650}: 0.3 \sim 0\right.$. 5). Ten microliters of purified peptide was added to $1 \mathrm{ml}$ of fungi suspension. In control samples, an equal amount of buffer was added into the bacterial suspension. The mixture was incubated for $20 \mathrm{hr}$ at $37^{\circ} \mathrm{C}$. The tubes were then transfered back to the icebath for stopping reaction. Anti-fungal activity was calculated by measuring the absorbance of $570 \mathrm{~nm}$ after incubation according to the following formula. $U=$ $\left(A_{0}-A\right) / A$, where $A$ is the absorbance in the sample and $A 0$ is the absorbance in the control[13].

\section{SDS-PAGE analysis}

Each active fraction collected from solid phase extraction and HPLC was loaded on $12 \%$ polyacrylamide gels, and electrophoresis of native proteins was carried out. The acrylamide/bisacrylamide ratio was 29.2: 0.8 , electrophoresis was performed at $200 \mathrm{~V}$ until the tracker dye was running off the gels.

\section{Assay of anti-fungal spectrum}

Anti-fungal spectrum was assayed of different active fractions obtained from solid phase extraction abided by the liquid growth inhibition assay as described previously. Fungi used for this assay were Candida albicans, Cryptococcus neoformans, Sporothrix schenckii, Rhizopus arrhizus, Pythium arolinianum, Fusarium oxysporum, Fusarium solani, Piricularia oryzae Cav, and Pythium sp offered by Guizhou Agriculture Institute, Guiyang, China.

\section{Heating-resistance stability of purified peptides}

After the last step of purification, the peak collected with anti-fungal activity was studied for figuring out the characterization of heating-resistance stability. This peptide was incubated in stepwise temperature from $50-100^{\circ} \mathrm{C}$ for $30 \mathrm{~min}$. strain 19 were vaccinated on thin agarose plates, filter paper (round in shape, diameter is $5 \mathrm{~mm}$ ) which contains $500 \mu \mathrm{l}$ fractions incubated in different temperature on thin agarose plates. Plates were incubated overnight at 3 $7^{\circ} \mathrm{C}$ and the diameters of zones were recorded. Anti-fungal activity was analyzed by measuring the fungi growth inhibition zones.

\section{Results and Discussion}

\section{Inducement and purification of anti-fungal peptides}

This investigation of the immune function of housefly led to the discovery of anti-fungal peptides. As shown in Fig. 1, vaccination of housefly pupae induced anti-fungal activities for $24 \mathrm{~h}$ in the hemolymph against C. Albicans. Simultaneously, weak activity was also detected in the control experiment as well as the hemolymph with induction. Active hemolymph was fractionated by Solid Phase Extraction (SPE). This step of purification gave ten fractions of which only three fractions had anti-fungal activity. They were fraction $30 \% \mathrm{ACN}, 60 \% \mathrm{ACN}$ and $70 \%$ ACN. Fig. 2 showed the anti-fungal activity after the further purification. Fraction $60 \% \mathrm{ACN}$ was further purified 

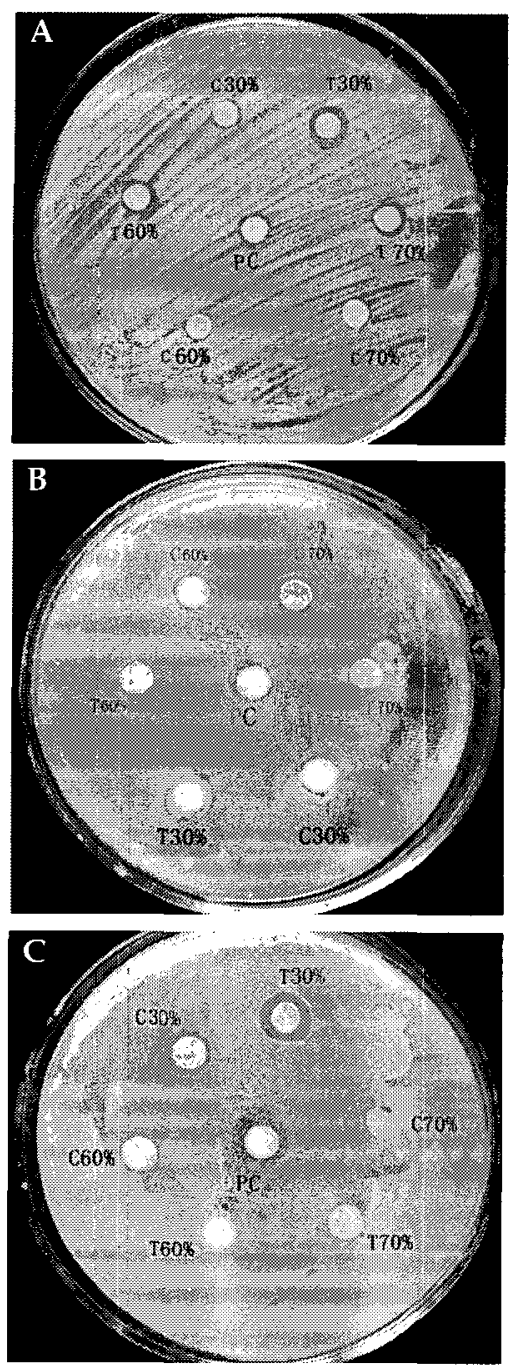

Fig. 1. Anti-fungal activity of SPE fractions eluted with different acetonitrile concentrations of induced and noninduced hemolymph on $C$. albicans cultured plates. where $A$ was strain 19, B was strain 09, C was strain 08; C 30\%, C60\% and $\mathrm{C} 70 \%$ were fractions eluted with $30 \% \mathrm{ACN}, 60 \%$ $\mathrm{ACN}$ and $70 \% \mathrm{ACN}$ of noninduced hemolymph; $\mathrm{T} 30 \%$, $\mathrm{T} 60 \%$ and $\mathrm{T} 70 \%$ were fractions eluted with $30 \% \mathrm{ACN}$, $60 \% \mathrm{ACN}$ and $70 \% \mathrm{ACN}$ of induced hemolymph, $\mathrm{PC}$ was positive control: Fluconazole. by HPLC and only one sub-fraction which appeared at around RT 27.5 min was obtained with anti-fungal activity. Fig. 3 illustrated different peaks performed through HPLC. It was obviously seen that the active peak appeared in the fraction $60 \% \mathrm{ACN}$ which was eluted from immunized hemolymph, while no the identical peak did in the control. These results proved that induction of microorganism can initiate the production of antimicrobial peptides. And of course, for the housefly itself, because of the potentially pathogenic environment around it, the antibacterial substances surely existed. Microorganisms which have succeeded in invasion the general body cavities by both cellular and humoral defenses. Housefly host defense is a multifaceted process, epithelial surfaces of the body serve as first-line defenses against microorganisms. Immediately after septic injury, the insect body fat (a homologue of mammalian liver) and some blood cells start to produce a battery of potent 20-40 amino acids-long antimicrobial peptides. These molecules

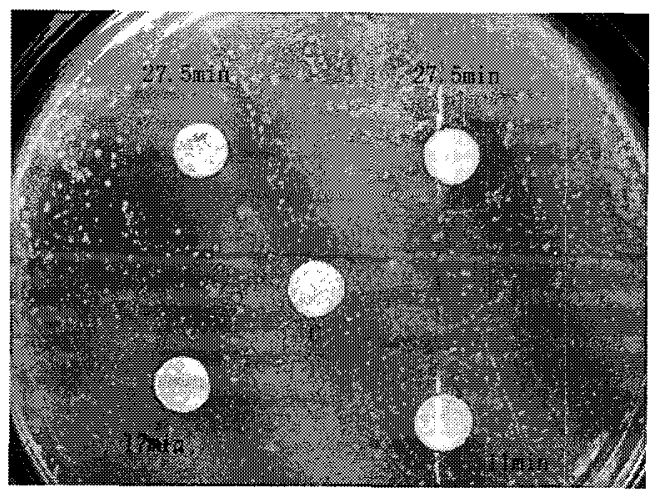

Fig. 2. The anti-fungal activity of HPLC (27.5min) fraction eluted with $60 \% \mathrm{ACN}$ of induced hemolymph on $\mathrm{C}$. albicans cultured plate 09 . Where $27.5 \mathrm{~min}, 17 \mathrm{~min}$ and $11 \mathrm{~min}$ were fractions of retain time $27.5 \mathrm{~min}, 17 \mathrm{~min}$ and $11 \mathrm{~min}$ of HPLC, $\mathrm{C}$ was positive control: Fluconazole.

Table 1. Anti-fungal activity zones of fractions through solid phase extraction eluted with different acetonitrile concentrations of hemolymph on C. albicans (mm)

\begin{tabular}{|c|c|c|c|c|c|c|c|c|c|c|c|c|}
\hline \multirow{2}{*}{\multicolumn{2}{|c|}{ Fungal Strains }} & \multicolumn{10}{|c|}{ Anti-fungal zones of eluted $\mathrm{ACN}$ fractions $(\mathrm{mm})$} & \multirow{2}{*}{$\frac{(\mathrm{n}=5)}{\text { Fluconazole }}$} \\
\hline & & 10 & 20 & 30 & 40 & 50 & 60 & 70 & 80 & 90 & 100 & \\
\hline \multirow{2}{*}{ Strain 08} & control & - & - & 9 & - & - & - & - & - & - & - & 16 \\
\hline & test & - & - & 15 & - & - & - & - & - & - & - & 16 \\
\hline \multirow{2}{*}{ Strain 09} & control & - & - & - & - & - & - & - & - & - & - & 11 \\
\hline & test & - & - & - & - & - & 9 & 10 & - & - & - & 11 \\
\hline \multirow{2}{*}{ Strain 19} & control & - & - & 6.5 & - & - & - & - & - & - & - & 9.5 \\
\hline & test & - & - & 8 & - & - & 10 & 11 & - & - & - & 9.5 \\
\hline
\end{tabular}



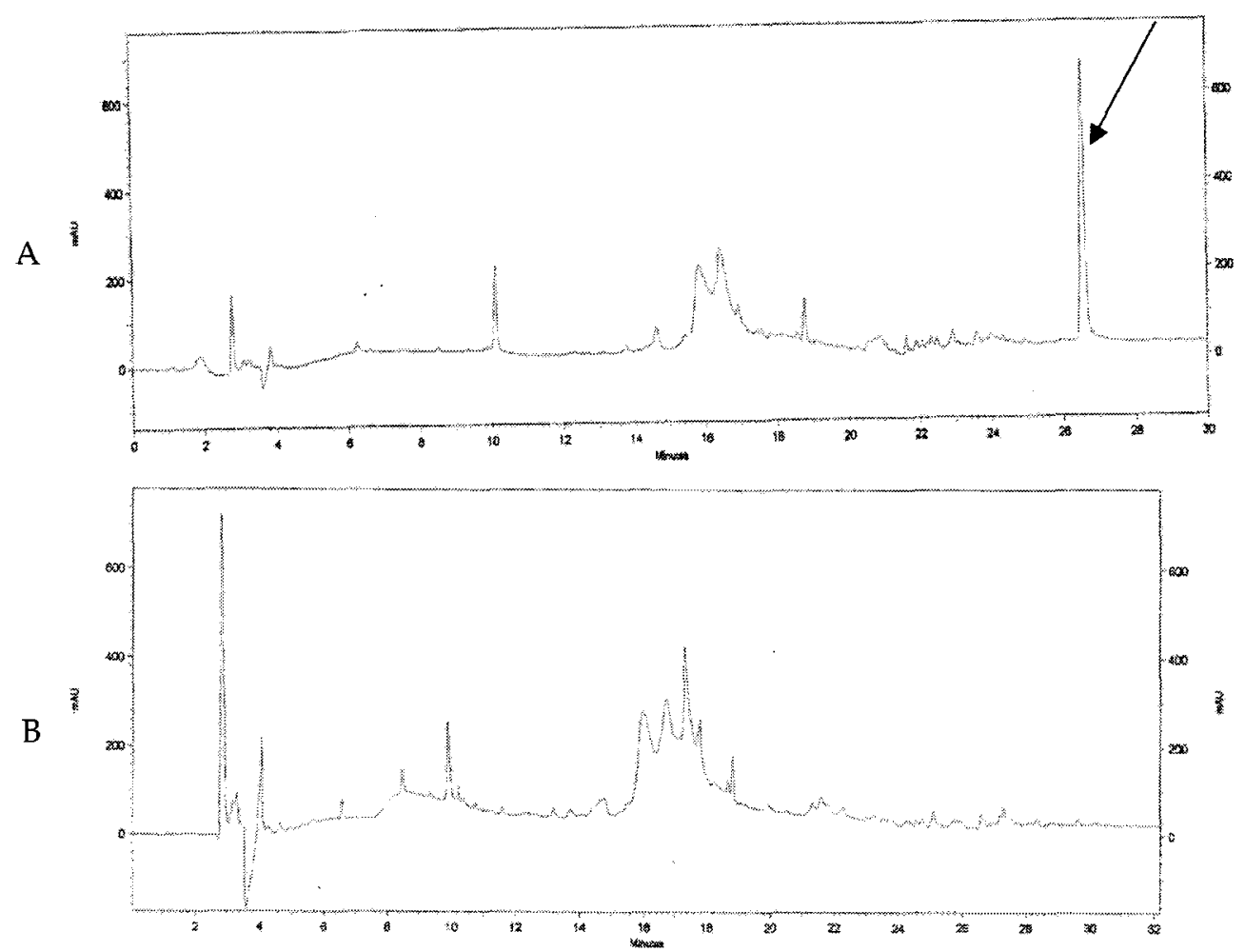

Fig. 3. RP-HPLC results of the fractions eluted with $60 \% \mathrm{ACN}$.where $\mathrm{A}$ was of induced hemolymph, $\mathrm{B}$ was noninduced hemolymph. $60 \% \mathrm{ACN}$ fraction from SPE was applied to a $\mathrm{C}_{18}$ column and eluted by a linear gradient of $25-100 \% \mathrm{ACN}$ in $0.1 \%$ TFA over $60 \mathrm{~min}$ at flow rates of $1 \mathrm{ml} / \mathrm{min}$. Arrow ' $\leftarrow$ ' indicated the different peak between induced and noninduced hemolymph.

are released into the blood, where they synergistically act to destroy the invading microorganisms. Many induced antimicrobial molecules are apparent in the hemolymph 2 4 $\mathrm{h}$ after infection at a concentration as low as $15 \mathrm{mM}$. In our study, the similar results can be obtained with the combination of SPE-HPLC methods.

\section{Anti-fungal activities of the purified peptides}

Elutions were collected after SPE, and the various fractions obtained from $\mathrm{ACN}$ extraction were tested for their antimicrobial activity by agarose plates medium and liquid growth inhibition assays against C. Albicans. The 30\% $\mathrm{ACN}, 60 \% \mathrm{ACN}$ and $70 \% \mathrm{ACN}$ Sep-Pak fractions were found to exhibit anti-fungal activity. But the anti-fungal activities of those three fractions aganist three strains of fungi were quite different. Table 1 and Fig. 1 gave a summary about the different anti-fungal activities against three strains of C. albicans. It can be seen that only fraction $30 \%$ ACN showed anti-fungal activity against strain 08 , while the activity of $60 \% \mathrm{ACN}$ and $70 \% \mathrm{ACN}$ fractions was not detected. Simultaneously, not only the immunized fly but also the control with $30 \% \mathrm{ACN}$ fraction exhibited anti-fungi activity. Inhibition zones of $30 \% \mathrm{ACN}$ fractions were 15 $\mathrm{mm}$ measured in immunized fraction and $9 \mathrm{~mm}$ in the control. Against strain 09, both $60 \% \mathrm{ACN}$ and $70 \% \mathrm{ACN}$ fractions exhibited the activity, while the activity of fraction $30 \% \mathrm{ACN}$ was not assayed against this strain. The fungi growth inhibition zones of immunized fractions $60 \% \mathrm{ACN}$ and $70 \% \mathrm{ACN}$ were $9 \mathrm{~mm}$ and $10 \mathrm{~mm}$, respectively. The activity against strain 09 was different from that of strain 08 because only immunized fractions $60 \% \mathrm{ACN}$ and $70 \%$ ACN exhibited the activity while the control which did not show the same activity. Furthermore, the activity of all the three fractions against strain 19 was observed and their fungi growth inhibition zones were $8 \mathrm{~mm}, 10 \mathrm{~mm}$, and 11 $\mathrm{mm}$, respectively. Meanwhile, the same results as we described previously against strains 08 and 09 can also be observed here against strain 19. Control $30 \% \mathrm{ACN}$ fraction showed the anti-fungal activity, but control fractions $60 \%$ $\mathrm{ACN}$ and $70 \% \mathrm{ACN}$ did not. To determine the different anti-fungi effect of purified fractions, liquid growth inhibition assay was also performed. The anti-fungal activity was represented by the formulation which was described previously. It can be obviously seen that the results were 
different with that detected in agarose plate. Table 2 gave more details. One possible explanation for the differences in activity was that the peptides may have different affinity for fungal cell membrane sterols and different membrane constituents of these particular antibiotic-resistant bacteria. This supported that the inducement might be due to chemical binding and not simply a physical entrapment of the soluble peptide. Other reason which could account for the difference of anti-fungal activity may lie in the different concentration after purification. Apparently, there was a concentration threshold below which these peptides do not interact with these fungal membrane constituents. These findings regarding substrate concentration indicated at least a partial reason to the difference in the lytic properties, and the subsequent lethality, of these and perhaps other peptides for fungi and other microorganisms.[6]

The heating-resistance stability of the purified peptides was further analyzed. Fig. 4 illustrated that this peptide was unaffected by heating at $50^{\circ} \mathrm{C}, 60^{\circ} \mathrm{C}, 70^{\circ} \mathrm{C}$ and $80^{\circ} \mathrm{C}$. However, after heating at $90^{\circ} \mathrm{C}$ and $100^{\circ} \mathrm{C}$, the anti-fungal activity showed decreasing trend. At those temperatures, peptide was not as stable as in the previous temperatures.

Table 2. Anti-fungal activity of $60 \% \mathrm{ACN}$ fraction of induced by hemolymph after HPLC

\begin{tabular}{|c|c|c|c|}
\hline \multirow{2}{*}{ Strains } & \multicolumn{3}{|c|}{ Anti-fungal activity $U$} \\
\hline & Induced & Uninduced & $P$ \\
\hline 08 & $0.307 \pm 0.0057$ & $0.290 \pm 0.0062$ & $<0.05$ \\
\hline 09 & $0.566 \pm 0.0374$ & $0.295 \pm 0.0047$ & $<0.05$ \\
\hline 19 & $0.480 \pm 0.0116$ & - & - \\
\hline
\end{tabular}

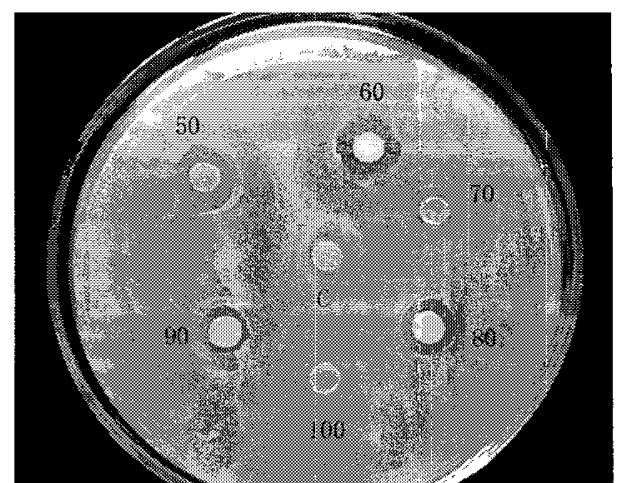

Fig. 4. The anti-fungal activity of the peptides after heating for $30 \mathrm{~min}$ under different temperatures. Where $50,60,70$, 80,90 and 100 were heating tempreatur, $C$ was positive control: Fluconazole.

Interestingly, even after being heated in $100^{\circ} \mathrm{C}$, the anti-fungal activity zones still can be detected. The studies conducted here demonstrated that by proofs of principles that those antimicrobial peptides stabilized themselives from degradation by high temperature which almost caused the denaturation of proteins. This was one of the peptide characteristics. The temperature simulation to those peptides performed in this study took the interactions among all atoms into account and calculated thermodynamic averages of physical quantities over a wide range of temperatures. We have found that for the peptides, there were two characteristic temperatures [24]. The temperature higher than $80^{\circ} \mathrm{C}$, was associated with a collapse of the peptides from extended coils into more compact structures; whereas that from $50^{\circ} \mathrm{C} \sim 80^{\circ} \mathrm{C}$, it indicated the transition between an ensemble of compact structures and a phase that was dominated by a single conformation,

Table 3. Anti-fungal spectrum of the peptides

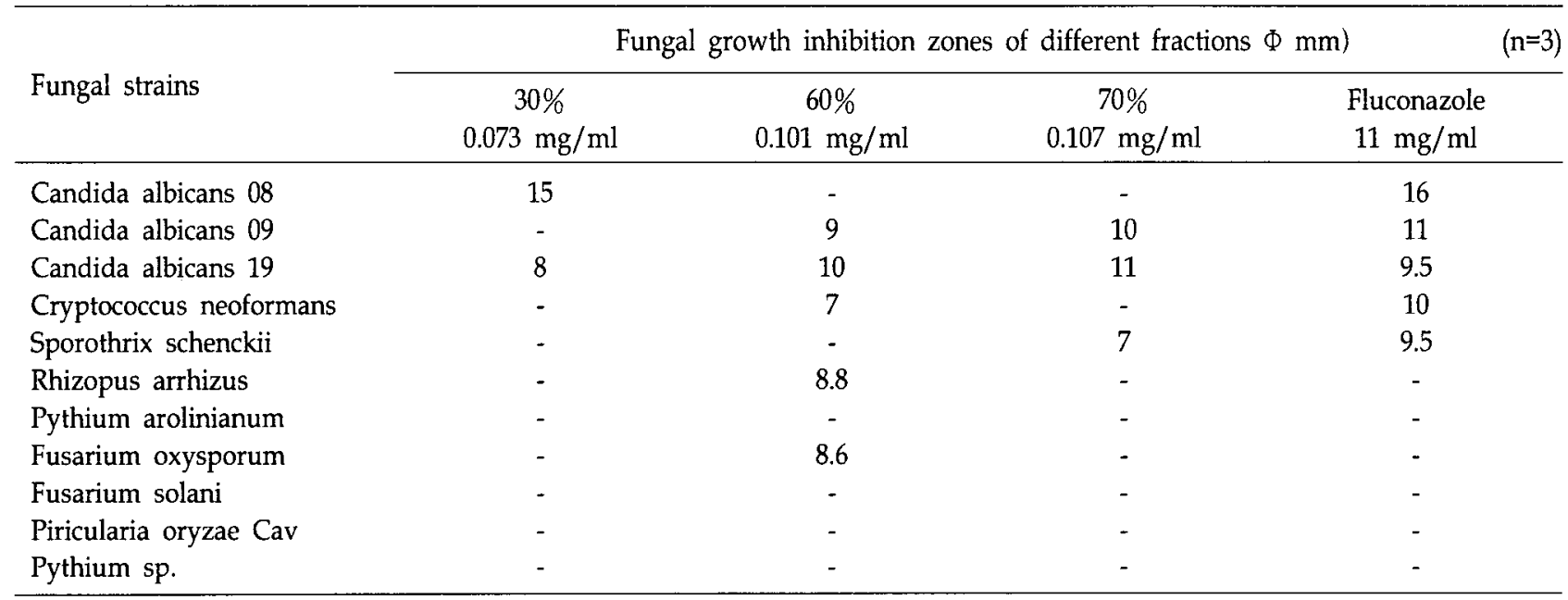


the ground state of the peptides. To investigate the anti-fungal spectrum of the purified peptides, the three fractions obtained from SPE were performed to assay the fungi growth inhibition zones against 11 fungal strains. Table 3 gave the results of anti-fungal spectrum. Except with the three strains of fungi $\mathrm{C}$. albicans, fraction of $60 \% \mathrm{ACN}$ also showed the anti-fungal activity against $C$. neoformans, $R$. arrhizus, and $F$. oxyspor. The inhibition zones were $7 \mathrm{~mm}, 8.8$ $\mathrm{mm}, 8.6 \mathrm{~mm}$, respectively. While fraction $70 \% \mathrm{ACN}$ showed activity against other two fungi C. neoformans and S. schenckii, the inhibition zones were $10 \mathrm{~mm}$ and $9.5 \mathrm{~mm}$, respectively. While fraction $30 \% \mathrm{ACN}$, showed only active against $C$. albicans strain 08 and strain 19. The peptides were tested for inhibitory activity against a variety of microorganisms. There was considerable variation in the observed activity against the fungal phytopathogens. In this study, the fungi used for activity detection were 12 strains wherein 8 strains could be inhibited by the three peptides. The peptide families were the potent inhibitors of the growth of some microbial pathogens in exhibiting inhibition. In this regard, those three peptides can compare with inhibitory activity at concentrations of less than 0.073 $\mathrm{mg} / \mathrm{ml}$. Also, those peptides exhibited a little wider spectrum of inhibitory activity with inhibition against several major taxonomic groups of microbes. These results suggested that those peptides commonly express the anti-fungal avtivity to a wide range of microbial organisms by acting on molecules and/or cell structures. Even though those peptides had a wider spectrum of inhibitory activity, they still did not exert the antif-fungal function to some other fungi. Like 4 strains of fungi which were tested here were either insensitive or only weakly sensitive to those peptides. These results suggested that there might also be some diversity in the mechanism of action of the three peptides against various microbes [17].

\section{Purification of peptides and SDS-PAGE}

Electrophoresis was one of the efficient ways to track of the purification efficacy and property of the peptides. After SPE and HPLC steps of purification, the fractions with anti-fungal activity were investigated on electrophoresis which was carried out in 12\% PAGE. The characterizations of peptides were obtained by PAGE. Fig. 5 offered the evidence of fraction $30 \% \mathrm{ACN}$ after the preparations contained the major components. The different bands moved between $4 \sim 16 \mathrm{kDa}$ can be obviously seen in induced fraction
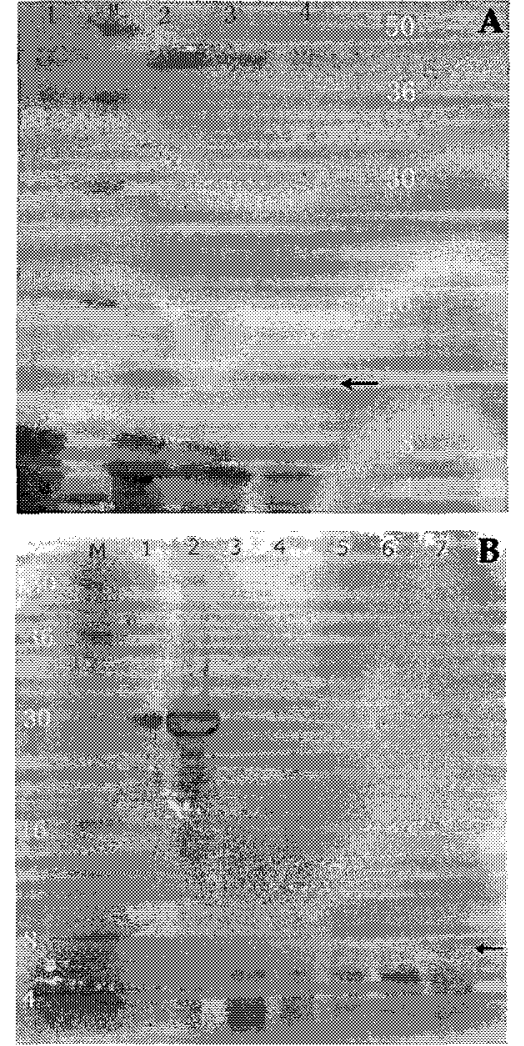

Fig. 5. SDS-PAGE of the fractions eluted with three concentration acetonitrile after SPE of both noninduced and induced hemolymphs (A) ( $30 \%$ acetonitrile fraction). Lane M: Protein standards; Lane 1, 2; the fractions eluted with $30 \%$ acetonitrile of induced hemolymph; Lane 3,4 : the fractions eluted with $30 \%$ acetonitrile of noninduced hemolymph; of elutions of $60 \%$ acetonitrile, $70 \%$ acetonitrile after SPE of control and induced hemolymph (B) (fractions $60 \%$ acetonitrile and $70 \%$ acetonitrile fractions). Lane M: Protein standards; Lane 1: The control hemolymph; Lane 2: The induced hemolymph; Lane 3, 4: the fractions eluted with $60 \%$ acetonitrile of noninduced hemolymph; Lane 6: the fraction eluted with $70 \%$ acetonitrile of noninduced hemolymph; Lane 5, 7: the fractions eluted with $60 \%$ acetonitrile and $70 \%$ acetonitrile of induced hemolymph. Arrow ' $\leftarrow$ ' indicated the different bands between induced and noninduced hemolymph.

against the control. Similar results can also be obtained of fractions $60 \% \mathrm{ACN}$ and $70 \% \mathrm{ACN}$. Both of the two fractions contained the different components which moved between $4 \sim 16 \mathrm{kDa}$ comparing to the control. The results indicated that the peptides could be a member of the 'peptide' class of insect antimicrobial proteins[5]. Fig. 6 showed that the isolated fraction $60 \%$ ACN from HPLC contained only single band located on $4 \sim 16 \mathrm{kDa}$ according to the standard marker, which provided a means to demonstrate 


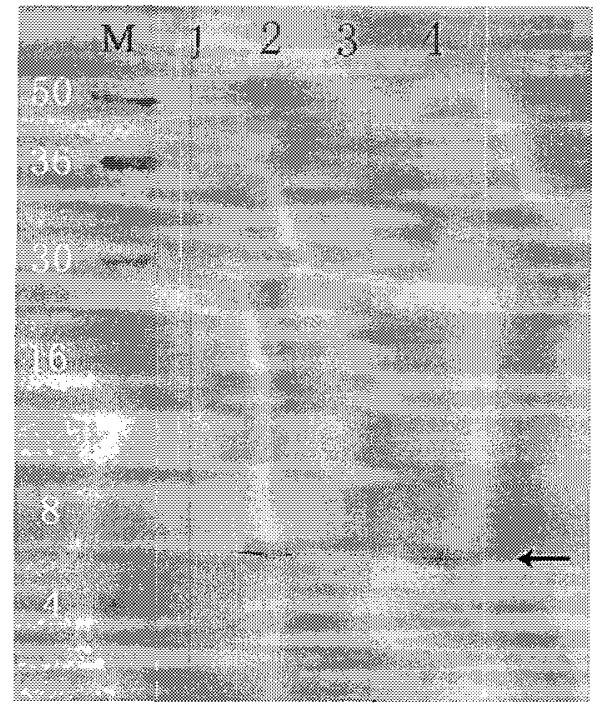

Fig. 6. SDS-PAGE electrophoresis of $60 \%$ acetonitrile fraction of hemolymph.

Lane M: Protein standards; Lane 1, 3: HPLC (27.5 min) fractions eluted with $60 \% \mathrm{ACN}$ acetonitrile of noninduced hemolymph; Lane 2, 4: HPLC (27.5 min) fractions eluted with $60 \% \mathrm{ACN}$ acetonitrile of induced hemolymph. Arrow ' $\leftarrow$ ' indicated the different bands between induced and noninduced hemolymph.

that this fraction after the step of purification was essential pure. This electrophoresis results summarized above demonstrated that hemolymph from induced housefly pupae contained at least three forms of peptides. These factors moved between the molecule weight of $4 \sim 16 \mathrm{kDa}$. The results provided the evidences that anti-fungal peptides can be purified by our SPE-HPLC purifaication methods, and this method can also be used for purification of the other similar peptides from insects.

Antimicrobial peptides play key physiological roles in prevention of fungal infections along mucocutaneous surfaces. The peptides can be the potential medicine in therapy of fungal infections in clinic, and also can be applied in agriculture research. Therefore, further exploration of the fungicidal properties of those three peptides is necessary and this work is still being performed.

\section{Conclusion}

The immune system of insects is characterized by its exquisite regulation. Insects antibacterial peptides play a key role in triggering immune responses to invasion of bacteria. And septic injury in housefly results in the production of antifungal peptides. The recent discovery of an- tibacterial peptides and their characteristic has allowed us to revisit the functional properties of this antibacterial peptides so that the appropriate molecular biology could be examined for possible exploitation for human welfare. In this present investigation, the antibacterial peptides were only partially purified. Research is also needed for extreme purification of the other peptides in order to determine the structure and sequence of the peptides.

\section{Acknowledgments}

We thank professor Yan Shi Hua, Guizhou Agriculture University for offering 7 Fungal strains. We are indebted to professor Qi Yi Min, Gui Yang Medical College for the precious advice in electrophoresis technical analysis, to professor Chen Han Bin, Gui Yang Medical College for stimulating discussions.

\section{References}

1. Boman, H. G. and D. Hultmark. 1987. Cell-free immunity in insects. Annu. Rev. Microbiol. 41, 103-126.

2. Boman, H. G., I. Nilsson-Faye, K. Paul and T. Rasmusin. 1974. Insect immunity. I. Characteristics of an inducible cell-free antibacterial reaction in hemolymph of Samia cynthia pupae. Infect. Immun. 10, 136-145.

3. Boman, H. G., I. Faye, G. H. Gudmundsson, J. Y. Lee and D. A. Lidholm. 1991. Cell-free immunity in Cecropia. A model system for antibacterical proteins. Eur. J. Biochem. 201, 23-31.

4. Bulet, P., C. Hetru, J. L. Dimarcq and D. Hoffmann. 1999. Antimicrobial peptides in insects; structure and function. Dev. Comp. Imimunol. 23, 329-344.

5. Broekaert, W. F., B. P. A. Cammue, M. F. C. De Bolle, K. Thevissen, G. W. De Samblanx and R. W. Osborn. 1996. Antimicrobial peptides from plants. Crit. Rev. Plant Sci. 16, $297-323$.

6. Delucca, A. J., J. M. Bland, C. B. Vigo, T .J. Jacks, J. Peter and T. J. Walsh. 2000. D-Cecropin B: proteolytic resistance, lethality for pathogenic fungi and binding roperties Medical Mycology 38, 301 - 308.

7. Fehlbaum, P., P. Bulet, S. Chernysh, J. P. Briand, J. P. Roussel, L. Letellier, C. Hetru and J. A. Hoffmann. 1996. Structure - activity analysis of thanatin, a 21-residue inducible insect defense peptide with sequence homology to frog skin antimicrobial peptides. Proc. Natl. Acad. Sci. USA. 93, $1221-1225$.

8. Fehlbaum, P., P. Bulet, L. Michaut, M. Lagueux, W. F. Broekaert, C. Hetru and J. A. Hoffmann. 1994. Insect Immunity Septis injury of drosophila induces the synthesis of a potent anti-fungal peptide with sequence ho- 
mology to plant anti-fungal peptides. J. Biol. Chem. 269, 33159 - 33163.

9. Hoebe, K., E. Jansen, and B. Beutler. 2004. The interface between innate and adaptive immunity. Nat. Immunol. 5, 971-974.

10. Hoffmann, J. A. 1995. Innate immunity of insects. Curr. Opin. Immunol. 7, 4-10.

11. Hoffmann, J. A., F. C. Kafatos, C. A. Janeway and R. A. B. Ezekowitz. 1999. Phylogenetic perspectives in innate immunity. Science 284, 1313-1318.

12. Hoffmann, J. A. and J. M. Reichhart. 2002. Drosophila, innate immunity, the evolutionary perspective Nature Immunology 3, 121-125.

13. Hultmark, D., H. Steiner, T. Rasmuson and H. G. Boman. 1980. Insect Immunity. Purification and properties of three inducible bacterial proteins from Hemolymph of Immunized Pupae of Hyalopnora cecropia. Eur. J. Biochem. 106, 7-16.

14. Hultmark, D. 1993. Immune reactions in Drosophila and other insects: a model for innate immunity. Trends Genet. 9(5), 178-183.

15. Ishibashi, J., H. S. Sakanaka, J. Yang, A. Sagisaka and M. Yamakawa. 1999. Purification, cDNA cloning and modification of a defensin from the coconut rhinoceros beetle, Oryctes rhinoceros. Eur. J. Biochem. 266, 616-623.

16. Lauth, A., Nesin, J. P. Briand, J. P. Roussel and C. Hetru. 1998. Isolation, characterization and chemical synthesis of a new insect defensin from Chironomus plumosus (Diptera). Insect. Biochem. Molec. 28, 1059 - 1066.

17. Marcus, J. P., K. C. Goulter, J. L. Green, S. J. Harrison and J. M. Manners. 1997. Purification, characterisation and cDNA cloning of an antimicrobial peptide from Macadamia integrifolia. Eur. I. Biochem. 244, 743-749.

18. Meister, M., C. Hetru and J. A. Hoffmann. 2000. The antimicrobial host defense of Drosophila. Curr. Top. Microbiol. Immunol. 248, 17-36.

19. Naraoka, T. and H. Uchisawa. 2003. Purification, characterization and molecular cloning of tyrosinase from the cephalopod mollusk, Illex argentinus. Eur. J. Biochem. 270, $4026-4038$.

20. Otvos, L. Jr. 2000. Antibacterial peptides isolated from insects. J. Pept. Sci. 6, $97-511$.

21. Reddy, K. V. R., R. D. Yedery and C. Aranha. 2004. Antimicrobial peptides: premises and promises. Int. J. Antimicrob. Ag. 24, 536-547.

22. Salzet, M. 2001. Vertebrate innate immunity resembles a mosaic of invertebrate immune responses. Trends Immunol. 22, 285-288.

23. Tasiemski, A., F. Vandenbulcke, G. Mitta, J. Lemoine, C. Lefebvre, P. E. Sautiere and M. Salzet. 2004. Molecular characterization of two novel antibacterial peptides inducible upon bacterial challenge in an annelid, the leech Theromyzon tessulatum. J. Biol. Chem. 279, 1-10.

24. Ulich, H. E., M. M. Hansmann and Y. Okamoto. 1997. Characteristic temperatures of folding of a small peptide. Proc. Natl. Acad. Sci. USA. 94, 10652-10656.

25. Zhao, X. K. and D. Y. Zhao. 2001. The progress of studies on insect antibacterial peptides. Acta Parasitologica et Medica Entomologica Sinica 8, 115-121.

\section{초록 : 집파리유충 hemolymph 중신형의 anti-fungal peptides의 분리정제}

Li-Juan $\mathrm{Gu}^{1,2} \cdot$ Jian-Wei Wu ${ }^{1 *} \cdot$ Xiao-Qing $\mathrm{Su}^{1} \cdot$ 성창근 $^{2}$

( ${ }^{1}$ 귀양의학원, 귀양 550004, 중국, ${ }^{2}$ 충남대학교, 농업생명과학대학, 식품공학과, 대전 305-764)

유도된 집파리유통 hemolymph중에서 Candida albicans의 3가지 anti-fungal peptides를 분리하였다. 3개 anti-fungal peptides는 분자량이 4-16 kDa 사이의 분명한 구별이 있을 뿐만 아니라, 각 peptide는 anti-fungal peptides 작용이 있었다. 이들 peptide의 공통 특징은 모두 열을 받은 뒤 활성이 변하지 않는 비교적 강한 내열성 을 보여주었다. 